\title{
Al-Quran Based Learning in Early Childhood Education
}

\author{
Nanda Colina ${ }^{1, *}$, Aan Listiana ${ }^{2}$ \\ ${ }^{1,2}$ Early Childhood Education, Universitas Pendidikan Indonesia, Bandung \\ *Corresponding author.Email: aanlistiana@upi.edu
}

\begin{abstract}
Al-Quran-based learning is learning that discusses problems in the Al-Quran, namely reading, memorizing, understanding and practicing the values contained therein to be applied in life, which in the Al-Quran itself is the value of life, so Every learning activity that has always been and always will be linked with the value contain in Al-Quran Therefore, teaching children about the Al-Quran would be very good because the Al-Quran is the main source in Islam. So it is clear that the purpose of learning Al-Quran is to make children more faithful and pious. In addition, Al-Quranbased learning or religious education in early childhood education also can to increase the value of religion in children. The purpose of this study is to describe how the implementation of Al-Quran-based learning in early childhood education. Data collection in this study was carried out with library data, reading, and taking note. The research approach was analysed using qualitative descriptive analysis.
\end{abstract}

Keywords: Al Quran based learning.

\section{INTRODUCTION}

Religious education is one of the compulsory subjects and aims to provide objective knowledge about religion in a pluralistic manner [1]. According to [2] religious education includes the totality of human behaviour, in which if the religion is good, then all of his behaviour will be based on faith and will form good morals which will become habits in his person and behaviour. If religious values are deeply embedded in a child, they will grow and develop with the ability to prevent and ward off and fortify themselves from various negative influences. In addition, religious education for young children should focus more on real life or experiences rather than complex religious concepts [3].

Embedding religious values in early childhood education is a shared responsibility, so that the values that are implanted are seen in children's behaviour and when children face problems in their lives. The teaching and learning process is not only limited to introducing the values of kindness to children but teaching children to practice them in their daily life [2].

In Islam itself it is said that education is never separated from aqidah or faith [4] which means that education is closely related to aqidah and faith. Further explained by [5] that religious education is education that can shape children's character from an early age. In addition, in Islam, Al-Quran is the main source in everything [6]. Al-Quran is also the holy book for Muslims which is used as a guide to the right path [7]. In other words, the Al-Quran was revealed to bring people from darkness to lightness.

Therefore, teaching Al-Quran to children is very good, especially if it is taught from an early age, because in Al-Quran there are the values of life [8]. Thus we need to teach children about the values contained in Al-Quran. Al-Quran-based learning is learning that examines the problems in Al-Quran [9], which includes reading, memorizing, understanding and practicing the values contained therein to be applied in life both in activities and in nature.

Specifically, in this article will describe how the importance of the learning based on Al-Quran and how implementation learning based on Al-Quran This discussion is also supported by the literature review begins with an understanding of learning based on $\mathrm{Al}$ Quran and then an understanding of how important $A l$ Quran based learning. 


\section{DISCUSSION}

\subsection{The Importance of Learning Based on Al- Quran}

The importance of religious education for students for religious education aims to develop knowledge and understanding of the students, to be appreciate other religions, able to face the problems faced in life, reason on the information obtained about religion, develop a sense of belonging and prepare them to live as a community compound, and reinforce the inquiry skills of students [10]. Besides religious education also aims to create a generation that has intelligence spiritual, spiritual intelligence here is not just about worship only but also on social relations. In other words, religion, dignity and civilization are part of spirituality [11].

However, the development of religious values in childhood is not achieved because of the children's behaviour that is not noble, bad moral quality, and a lack of concern for the school environment. Internal and external factors that become the achievement of religious-moral values in children because the curriculum with religious content is too heavy and does not focus on developing values in daily life and moral development, but rather focuses on memorizing. This shows the importance of planting religious education in early childhood [12].

Al Quran functions to develop human thinking and regulate attitudes and emotions both in personal and public interests, in the $\mathrm{Al}$ Quran there are values such as the values of faith, sharia and morals which are basic values, besides that there are also local values. This brings a difference between one another, between one place and another and these differences are acceptable as long as they do not contradict the teachings contained in the Al Quran [7].

That the importance of learning Al-Quran can be seen from several thing that is on purpose in teaching and studying the Al-Quran thus learning [9]. Al-Quran will form a good character as the highest goal of Islamic education. Learning based on Al-Quran birth to an Islamic generation and spawned generations as true in accordance with the teachings of Al-Quran and can develop all potential learners to become a man of faith and devoted to the creator [13].

According to Samak in [9] that the purpose of teaching the Al-Quran to students is as follows.

1. To explain the main base in Islamic law.

2. To increase the thinking power of students about life.

3. To provide explanation and understanding of the verses he has studied.
4. So that students know the religious laws contained in the Al-Quran and remember to memorize and practice them.

5. So that students have character and have good morals.

In other words, provide an understanding of the verse of Al-Quran and carried through memorizing and reading, students are accustomed to memorize verses of the Quran in accordance with the contents of the content of paragraph and carried out gradually with the adjustment with all of student's potential.

\section{IMPLEMENTATION LEARNING BASED ON THE QURAN}

Religious education is education that aims to see oneself from a different angle [14], and to know that all creatures are the creation of the creator as well as a learning process and conscious effort to make students a moral generation [3]. Found religious education for children small should be more focus on real life or experience there is a complex concept of religion. Sometimes in education, religious elements occur accidentally, especially in early childhood education [15].

PAUD is an important part in participating and contributing in instilling religious values. The inculcation of religious values can be done by instilling positive things in children so that the children will become a religious generation [11]. In Islam, Al-Quran is the source of all problems so that learning it is an obligation for all Muslims. Learning Al-Quran is very good especially when it starts from childhood, the introduction of the Al-Quran from an early age makes the Al-Quran a guide in life based on the spiritual values contained in the Al Quran [16].

Al-Quran is the main guideline in Muslims and is the word of Allah that was revealed to the Prophet, so that Al-Quran is considered an unquestionable truth in which it teaches many things related to life [6]. Thus, making Al-Quran as the basic foundation of various scientific fields, it will instil in our students that Al-Quran is the source of knowledge. Implementing Al-Quran -based learning [16], students must be instilled in the Al-Quran as the main guide in digging up all information, therefore Al-Quran based learning is very important in order to create a generation that is strong and not easily shaken to the temporary pleasures of the world because real life is the hereafter, thus knowing the purpose of his life, namely the creator, really needs to be instilled from an early age.

$\mathrm{Al}$ Quran provides a basic foundation in the world of education [13]. When viewed education in a modern context, all material in the world of education has been summarized as follows: 
1. From the point of view of educational goals in the letter Al-furqan verse 74, Islam formulates the figure of piety

2. From a psychological perspective, parents want to tell their children to read Al-Quran and practice the contents of the Al-Quran

3. And seen from the side of the curriculum, education can be seen from the letter $A l$-jumuah in verse 2 of the recitation stages of tazkiah and wisdom.

There are four aspects that are the reasons for implementing Al-Quran-based learning [9], including: (1) dogmatic aspect, namely believing that the Quran is the guide and source of human life. Al-Quran does not only discuss about spiritual life, but also discusses teachings that are holistic, comprehensive, and universal. (2) socio-cultural aspect. That is, people who are Muslim have a culture that cannot be separated from the $\mathrm{Al}$ Quran. (3) Political aspects. Namely, as explained in Law Number 20 of 2003 concerning the National Education System, Article 3, states that the purpose of education is to develop all of students potential to become human beings who believe and fear God Almighty, have noble character, knowledgeable, competent, creative, independent, being responsible.

Based on this explanation, the words "faith and taqwa" are clear from the contents of Al-Quran. In the view of Islam itself, it is impossible for someone to be able to believe and be pious without practicing the contents of the Al-Quran. Therefore, studying the AlQuran is an obligation for all Muslims. (4) Historical aspects. Al-Quran highly appreciates the past and is perpetuated so that it is used as a basis for overcoming various problems in every era [7]. Therefore, one of the contents of the Quran and a part of the Quran is a story or namely qasas which means pieces of history. Al-Quran also contains trans-historical values, because the $\mathrm{Al}$ Quran was revealed in historical reality.

The scope of Al-Quran education is writing, reading, understanding and memorizing verses from $\mathrm{Al}$ Quran and selected verses as well as exemplifying the values contained in Al-Quran as well as training and getting used to reading Al- Quran to students and practicing the contents of its contents in everyday life, and it is also said that Al Quran education in schools serves as an introduction, habituation, prevention, and inculcation of values [9].

Based on the explanation it is clear that the application of learning based on Al-Quran do with habituation such as ablution, prayer five times a day, the introduction of the creator creation, linking all the materials learning with Al Quran.

\section{CONCLUSION}

PAUD is one of school and an important part of participating and contributing to instilling religious values. Inculcating religious values can be done by instilling in children positive things so that children will become a religious generation. In Islam, Al Quran is the basic foundation for all Muslims, therefore learning the Quran is an obligation for all Muslims. Al-Quran-based learning is learning that examines problems in the Quran such as reading, memorizing and understanding the contents of the contents and practicing them in everyday life. The importance of learning based on Al-Quran can be seen in the purpose of teaching and learning it so that it will make children pious, believing which is the highest goal in Islamic education. In the application of Al-Quranbased learning, educators need to still in students to make the Al Quran the main guide in dealing with all problems in life. There are 4 important aspects for implementing Al-Quran based learning, including: dogmatic aspect, socio-culture aspect, politic aspect and history aspect. $\mathrm{Al}$ Quran-based learning is very important because introducing the Al Quran from an early age is very good so that children become a strong generation and have good morals.

\section{REFERENCES}

[1] Reimers E. Secularism and religious traditions in non-confessional Swedish preschools: Entanglements of religion and cultural heritage. British Journal of Religious Education. 2020;42(3):275-84. Available from: https://doi.org/ 10.1080/01416200.2019.1569501.

[2] Julianti S, Rustam R, Kasmiati K. Implementasi penanaman nilai-nilai religius pada anak usia dini di tk dharma wanita tibo kecamatan sindue tombusabora kabupaten donggala. 2020;1(1):77-89.

[3] Grajczonek J. Spiritual development and religious education in the early years: A review of the literature. Unpublished Report, Queensland Catholic Education Commission. 2010;42. Available at: http://www.qcec.catholic.edu.au/wpcontent/uploads /2015/12/Final_SpiritualDevelopment-ReligiousEducation-in-the-Early-Years_A-Review-of-theLiterature.pdf.

[4] Afifah N, Suriansyah A, Aslamiah A. Implementation of Islamic aqeedah based curriculum at khoiru ummah tahfizh plus kindergarten. Journal of K6 Education and Management. 2019;2(1):47-57.

[5] Isnaningsih A, Rohman A. Intervention of "Religious activities" instilling the character of the responsibility in early childhood to welcome revolution 4.0. In 3rd International Conference on Learning Innovation and Quality Education (ICLIQE 2019) [internet]. 2020:34-44. Atlantis 
Press. Available from: https://dx.doi.org/10.2991/ assehr.k.200129.005.

[6] Sai Y. Teaching Qur'an in Irish muslim schoolscurriculum, approaches, perspectives and implications. British Journal of Religious Education. 2018;40(2):148-57. Available from: http://dx.doi .org/10.1080/01416200.2016.1269723

[7] Yusuf M. Membentuk karakter melalui pendidikan berbasis nilai. Al-Ulum. 2013;13(1):1-24.

[8] Kuusisto A, Gearon L. Why teach about religions? Perspectives from finnish professionals. Religions. 2019;10(6):1-16.

[9] Hakim R. Pembentukan Karakter peserta didik melalui penidikan berbasis Al Quran. Pendidik Karakter. 2014;2:123-36.

[10] Munadi M, Rahayu W. Inculcation religiosity in preschoolers local content curriculum. Jurnal Pendidikan Usia Dini. 2019;13(2):201-16.

[11] Inawati A. Strategi pengembangan moral dan nilai agama untuk anak usia dini. Al-Athfal: Jurnal Pendidikan Anak. 2017 Aug 1;3(1):51-64.

[12] Yani A. Kurikulum berbasis Al-Quran (KBQ) alternatif pengembangan sekolah unggulan [internet]. 2003:1-11. Available from: http://file.upi.edu/Direktori/FPIPS/JUR._PEND._G EOGRAFI/196708121997021AHMAD_YANI/Arti kel_Pengembangan_Kurikulum_Berbasis_Alquran. pdf.

[13] Buchanan MT, Gellel AM, editors. Global perspectives on catholic religious education in schools: Learning and leading in a pluralist world [internet]. Springer; 2019 Mar 1. Available from: http://dx.doi.org/10.1007/978-981-13-6127-25.

[14] Abo-Zena MM, Midgette A. Developmental implications of children's early religious and spiritual experiences in context: A sociocultural perspective. Religions. 2019;10(631):1-16.

[15] Saifuddin S, Amalia IA. Pengelolaan pembelajaran Alqur'an di RA (studi kasus pengguna metode qiraati). AWLADY: Jurnal Pendidikan Anak. 2018;4(1):119-28.

[16] Komariah N. Kurikulum berbasis Al-quran (kbq) pada anak usia dini. Al-Afkar: Jurnal Keislaman \& Peradaban. 2015;3(1):71-98. 